\title{
Simple Models for the Continuous Aerobic Biodegradation of Phenol in a Packed Bed Reactor
}

\author{
Andrew Mark Gerrard ${ }^{1 *}$, Jan Páca Júnior ${ }^{2}$ Alena Kostečková ${ }^{3}$ Jan Páca $^{3}$, Marie \\ Stiborová $^{2}$ and Carlos Ricardo Soccol ${ }^{4}$ \\ ${ }^{1}$ University of Teesside, School Of Science and Technology; Middlesbrough; England TS1 3BA; \\ a.m.gerrard@tees.ac.uk. ${ }^{2}$ Department of Biochemistry, Faculty of Science, Charles University, Albertov 2030,128 \\ 40 Prague 2, Czech Republic; jan.paca@volny.cz. ${ }^{3}$ Department of Fermentation Chemistry and Bioengineering; \\ Institute of Chemical Technology; Technická 5, 16628 Prague 6; Czech Republic; Jan.Paca@vscht.cz. \\ ${ }^{4}$ Universidade Federal do Paraná; Centro de Tecnologia; Divisão de Engenharia de Bioprocessos e Biotecnologia; \\ soccol@upfr.br; 81531-970; Curitiba - PR - Brasil
}

\begin{abstract}
This paper proposes the use of a preliminary, phenol removal step to reduce peak loads arriving at a conventional effluent plant. A packed bed reactor $(P B R)$ using polyurethane foam, porous glass and also cocoa fibres as the inert support material was used. Experiments have been carried out where the flow-rates, plus inlet and outlet phenol concentrations were measured. A simple, plug-flow model is proposed to represent the results. Zero, first order, Monod and inhibited kinetics rate equations were evaluated. It was found that the Monod model gave the best fit to the experimental data and allowed linear graphs to be plotted. The Monod saturation constant, K, is approximately $50 \mathrm{~g} \mathrm{~m}^{-3}$, and $\mathrm{ka}$ is around $900 \mathrm{~s}^{-1}$.
\end{abstract}

Key words: Biodegradation, phenol, aerobic reactor, models

\section{INTRODUCTION}

Phenol is an aromatic pollutant, which is present in the wastewaters of numerous industries including oil refining, petrochemical, coal-coking and coalgasification (Singer et al., 1977). Decades of operations involving the leaking of gaskets, plus bad handling and technical troubles can contaminate soil and ground-waters with phenolic compounds. For example, during cleaning and washing periods, the concentrations in the waste waters may exceed the limiting value that can be treated by conventional biological methods using activated sludge (Watanabe et al., 1996) without harming its normal function. This problem can be solved by the use of a preliminary cleaning step. For example, this could be a specially designed packed bed reactor containing immobilized cells to reduce these peak loads. In addition, similar equipment and technology can be used for a "pump-up and clean" procedure at any location with phenol contaminated soils and ground-waters. The degradation of phenol can be performed under aerobic (Hinteregger et al., 1992; Chitra et al., 1995; Oh and Han, 1997) or anaerobic processes (Bechard et al., 1990) by pure (Heipieper et al., 1991) or mixed cultures (Ehrhardt and Rehm, 1985; Mörsen and Rehm, 1990; Mörsen and Rehm, 1987, Páca Jr. et al., 2005). As proved experimentally (Zache and Rehm, 1989), an

\footnotetext{
${ }^{*}$ Author for correspondence
} 
application of the mixed culture permits faster phenol degradation than a pure culture. In addition, the systems with immobilized cells are more stable to shock loadings than the submerged cultures with free cells (Holladay et al., 1978). Pseudomonas is a bacterial genus commonly found in waste water plants and Pseudomonas putida is a species capable of using phenol as a major source, which has been studied (Bayly and Wigmore, 1973; Yang and Humphrey, 1975). In addition, fungi including Trichosporon cutaneum and Candida tropicalis are capable of utilizing phenol as the major carbon and energy source (Neujahr and Varga, 1970; Neujahr et al., 1974; Krug et al., 1985; Krug and Straube, 1986; Stephenson, 1990; Komárková and Páca, 2000; Komárková et al., 2003; Páca et al., 2002; Ahuatzi-Chacon et al., 2004). The aim of the study was to evaluate various packing materials that can be used on an industrial scale in packed bed reactors with immobilized cells in a biofilm. In addition, the kinetic constants of phenol biodegradation have been evaluated.

\section{MATERIALS AND METHODS}

\section{Packed Bed Reactor, Microbial Culture, Growth Media}

This study was focused on an aerobic phenol biodegradation in continuously operated packed bed reactors (PBR). The bench-scale reactors had a diameter of $50 \mathrm{~mm}$, an overall volume of 614 $\mathrm{mL}$ and a working volume of $196 \mathrm{~mL}$ (Fig. 1). The degradations proceeded under non-aseptic conditions at $30^{\circ} \mathrm{C}$ and an inlet $\mathrm{pH}$ value of 7.2. The reactors were operated with a co-current upflow of air and liquid effluent. Phenol biodegradation experiments in reactors were carried out with the following diluted mineral medium (MM) (per $1 \mathrm{~L}$ volume): $0.3 \mathrm{~g} \mathrm{~K}_{2} \mathrm{HPO}_{4}$; $0.2 \mathrm{~g} \mathrm{KNO}_{3} ; 0.2 \mathrm{~g} \mathrm{MgCl}_{2} \cdot 6 \mathrm{H}_{2} \mathrm{O}$ and $1 \mathrm{~mL}$ of a trace element solution. The following packing materials were used: polyurethane foam, porous glass balls and cocoa fibres. An enriched mixed microbial culture (Pseudomonas putida S7, Comamonas testosteroni $\mathrm{Pb} 50$ and Candida tropicalis $\mathrm{Ct} 2$ ) served as a catalyst for the phenol degradations (Páca Jr. et al., 2005). All the strains are from the collection of the Laboratory of Bioengineering at the Institute of Chemical
Technology Prague. The microbial biomass for immobilization was prepared in two-stage precultures using shaking flasks at $30{ }^{\circ} \mathrm{C}$ and $\mathrm{pH}$ 7.2. The first cultivation lasted 1 day and the second cultivation in the mineral medium (MM) was for 3 days. Phenol was added at the beginning of the cultivation $\left(350 \mathrm{mg} \cdot \mathrm{L}^{-1}\right)$ and then after $6 \mathrm{~h}$ each day, in a quantity to achieve its final concentration of $350 \mathrm{mg} . \mathrm{L}^{-1}$. The medium contained (per $1 \mathrm{~L}$ volume): $4.3 \mathrm{~g} \mathrm{~K}_{2} \mathrm{HPO}_{4} ; 3.4 \mathrm{~g}$ $\mathrm{KH}_{2} \mathrm{PO}_{4} ; 2.0 \mathrm{~g}\left(\mathrm{NH}_{4}\right)_{2} \mathrm{SO}_{4} ; 0.34 \mathrm{~g} \mathrm{MgCl}_{2} \cdot 6 \mathrm{H}_{2} \mathrm{O}$ and $1 \mathrm{~mL}$ of trace element solution. Trace elements contained (per $1 \mathrm{~L}$ volume): $0.3 \mathrm{mg}$

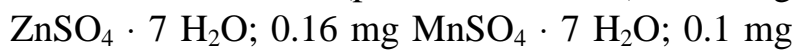
$\mathrm{FeSO}_{4} \cdot 7 \mathrm{H}_{2} \mathrm{O} ; 0.1 \mathrm{mg} \mathrm{CuSO} \mathrm{H}_{4} \cdot 5 \mathrm{H}_{2} \mathrm{O} ; 0.1 \mathrm{mg} \mathrm{Co}$ $\mathrm{SO}_{4} \cdot 7 \mathrm{H}_{2} \mathrm{O} ; 0.1 \mathrm{mg} \mathrm{NaBO}{ }_{2} ; 0.1 \mathrm{mg} \mathrm{Na} \mathrm{Mo}_{2} \mathrm{O}_{7}$; $0.15 \mathrm{mg} \mathrm{CaSO}_{4} \cdot 1 / 2 \mathrm{H}_{2} \mathrm{O}$.

The measured parameters were: the phenol concentrations at inlet and outlet, temperature, $\mathrm{pH}$ and dissolved oxygen tension in the water outflow, together with the volumetric flow-rates of water and air. The loading characteristics were tested. Various hydraulic retention times and loading rates were used. (In the reactor which was filled with polyurethane foam, the nitrogen content of the aqueous medium was also varied.)

Phenol was determined by HPLC with a UV detector (Spectro monitor 3200 set at $270 \mathrm{~nm}$ ) and column (Nucleosil 12-5 C18, 250 x 4 mm, Watrex, Prague, Czech Rep.) under isocratic conditions (eluent mixture methanol - water $-\mathrm{H}_{3} \mathrm{PO}_{4}, 50: 49$ : 1). The signal was evaluated by Chromatography Station for Windows version 1.7 (CSW). The dissolved oxygen concentration was determined using a Pt- $\mathrm{Ag}-\mathrm{AgCl}$ electrode coupled with Oxytest analyzer (Developmental Workshop, Academy of Sciences of the Czech Rep., Prague). The dissolved oxygen concentration (DOC) is a percentage of its saturation concentration in the diluted MM. The porosity of the packing materials was determined according to the method of Hopp and Huegele (1996).

The polyurethane foam data consisted of some 30 data points and the sintered glass bead data $(85$ experiments) was subdivided into two groups with different levels of nitrogen, in order to determine the effect of this variable. Using cocoa fibres, some 108 experiments were carried out, (varying the inlet concentrations and flow rates). 


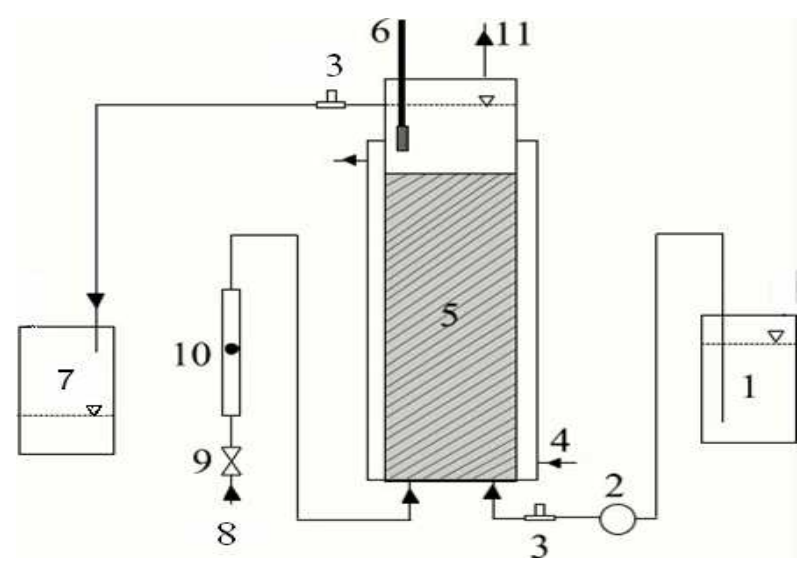

Figure 1 - Experimental setup: 1 - container with phenolic medium, 2 - membrane pump, 3 - sampling port, 4 - tempering jacket, 5 - packing, 6 - combined electrode for dissolved oxygen concentration and temperature, 7 - container with treated medium, 8 - air inlet, 9 - needle valve, 10 - rotameter, 11 - air outlet.

\section{Modelling the Process}

A simple kinetic model to represent the degradation characteristics found in the laboratory is now outlined. As noted above, the major independent variables were the flowrate, $Q$, and inlet concentration, $C_{i n}$, of the phenol bearing stream. The outlet concentration, $C_{\text {out }}$, was measured for a number of process conditions and bed materials. Assuming that there was no growth during the experiments and also that there was no diffusional resistance within the biolayer then the usual plug flow design equation may be used:

$$
V=\frac{Q}{(1-e) a} \int_{C_{\text {in }}}^{C_{\text {out }}} \frac{d C}{-r}
$$

where $V$ is bed volume and $a$ is the (dry weight) biomass per volume of packing, and the apparent reaction term, $r$, is defined as:

$$
r=\text { phenol removed } / \text { (time } . \text { biomass) }
$$

If zero kinetics are assumed, where $r=r^{*}$ is a constant, then equation 1 is easily integrated to give the well known linear relationship between QCin and QCout.

$$
V=\frac{-Q}{(1-e) r^{* a}}\left[\left(C_{\text {out }}-C_{\text {in }}\right)\right]
$$

If first order kinetics are assumed, where $r=k C$, then we obtain:

$$
V=\frac{-Q}{(1-e) k a}\left[\ln \frac{C_{\text {out }}}{C_{\text {in }}}\right]
$$

Here, we expect a linear relationship between $Q \ln$ $C_{\text {in }}$ and $Q \ln C_{\text {out }}$

However, the Monod form is a more powerful and realistic representation of removal kinetics and has the form:

$$
r=\frac{k C}{K+C}
$$

where $k$ and $K$ are constants.

putting this into equation 1 gives:

$$
V=\frac{-Q}{(1-e) k a}\left[\left(C_{\text {out }}-C_{\text {in }}\right)+K \ln \frac{C_{\text {out }}}{C_{\text {in }}}\right]
$$

This can be rewriten as:

$$
Q\left(C_{\text {out }}+K \ln C_{\text {out }}\right)=Q\left(C_{\text {in }}+K \ln C_{\text {in }}\right)-(1-e) k a V
$$


In this form, the data can be linearised by guessing $K$ and plotting each $Q(C+K \ln C)$ term on linear paper and choosing the value of $K$ which gives the best straight line (by maximising the coefficient of determination, $R^{2}$ ). Clearly, the slope is expected to be unity and the intercept to be negative.

If necessary, the Monod type equation can be extended to include substrate inhibition by adding an extra term $\left(F C^{2}\right)$ to the denominator, where $F$ is an extra constant to be fitted to the data, thus:

$$
r=\frac{k C}{K+C+F C^{2}}
$$

Integrating equation 1 with this gives:

$$
V=\frac{-Q}{(1-e) a k}\left[\left(C_{\text {out }}-C_{\text {in }}\right)+K \ln \frac{C_{\text {out }}}{C_{\text {in }}}+\frac{F}{2}\left(C_{\text {out }}{ }^{2}-C_{\text {in }}{ }^{2}\right)\right]
$$

and collecting terms:

$$
Q\left(C_{\text {out }}+K \ln C_{\text {out }}+\frac{F}{2} C_{\text {out }}^{2}\right)=Q\left(C_{\text {in }}+K \ln C_{\text {in }}+\frac{F}{2} C_{\text {in }}^{2}\right)-(1-e) k a V
$$

Again, this equation can be linearised, this time by guessing both $K$ and $F$, so that $R^{2}$ is maximised when each $Q\left(C+K \ln C+F C^{2} / 2\right)$ term is plotted on linear axes. These ideas will enable a preliminary estimate of the best values of the various coefficients, $K, k a$ and $F$ to be made etc.
Another approach to the fitting of parameters is to rearrange equation 10 (or the simpler version e.g. equation 7 etc.) to minimise directly the sum of the squares, $y$, summing over all the data points:

$$
y=\sum\left[-Q\left(C_{\text {out }}+K \ln C_{\text {out }}+\frac{F}{2} C_{\text {out }}{ }^{2}\right)+Q\left(C_{\text {in }}+K \ln C_{\text {in }}+\frac{F}{2} C_{\text {in }}{ }^{2}\right)-(1-e) k a V\right]^{2}
$$

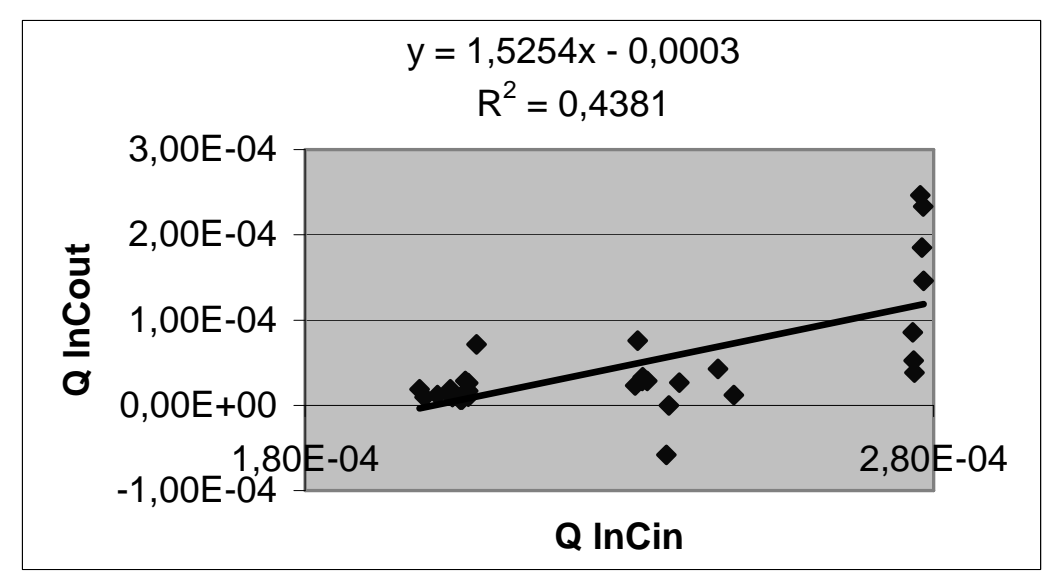

Figure 2 - First order model with the polyurethane foam. 


\section{RESULTS}

\section{Polyurethane Foam}

This data exhibited a large measure of spread, especially at high $C_{i n}$ values, and the plotting of the zero order model using equation 3 gave a very poor coefficient of determination (only 0.18.) The logarithmic plotting of equation 4 did give a small improvement $\left(R^{2}=0.44\right)$, see Fig. 2 . The Monod model was found to be unable to improve on this fit. With this degree of spread in the data, the estimation of the kinetic parameters was not attempted.

\section{Porous Glass Packing}

The experiments were similar to those reported above, but an additional parameter to be varied was the inlet nitrogen content which was set at a high and a low level, $\left(0.2\right.$ and $\left.0.71 \mathrm{~g} \mathrm{~L}^{-1}\right)$.

For the lower nitrogen level, it was found that a zero order model was marginally superior to a first order model (the $R^{2}$ values were 0.64 and 0.61 ) and that a small improvement could be made by adding the extra constant, $K$, of the Monod model, ( $R^{2}$ rose to 0.66 when $K=19 \mathrm{~g} \mathrm{~m}^{-3}$ ), see Fig. 3. From the intercept, $k a$ is estimated to be around $950 \mathrm{~s}^{-1}$.

For the higher level nitrogen conditions, the fits were much poorer. The Monod model gave the best results, $\left(R^{2}=0.46\right.$, when $K=15 \mathrm{~g} \mathrm{~m}^{-3}$, a similar value to the one obtained in the previous experiments).

\section{Cocoa-Fibres}

This constituted the largest set of data. The zero and first order models gave similar $R^{2}$ values,
(0.73 and 0.74). When Monod model was used, there was an increase in the coefficient of determination (to 0.90) when $K$ was set equal to $100 \mathrm{~g} \mathrm{~m}^{-3}$. Fig. 4 shows that the gradient is indeed around unity and the intercept gives the value of -(1-e)kaV.

From this, $k a$ is found to equal $1400 \mathrm{~s}^{-1}$. However, at the top right hand corner of the graph, we see a group of data points diverging upwards and away from the line of best fit at high inlet concentrations, indicating that there may be a substrate inhibition effect.

Equation 10 was then used to fit the data. By increasing $K$ to $430 \mathrm{~g} \mathrm{~m}^{-3}$ and setting $F=0.005$ $\mathrm{m}^{3} \cdot \mathrm{g}^{-1}$, the best fit to date was obtained, with $R^{2}$ equalling 0.928. (The slope is still close to unity, and the intercept value is negative as expected (Fig. 5) leading to a $k a$ value of $4982 \mathrm{~s}^{-1}$ ).

However, it is arguable if the complication of including the extra parameter $(F)$ is worth the $3 \%$ improvement in the $R^{2}$ value. In order to investigate this further, the other objective function, $y$, was used, see equation 11. Starting from the values just mentioned, the Solver routine in Excel was used to vary the values of $K, k a$ and $\mathrm{F}$ to minimise $y$. It was found that $y$ was improved from 0.17 to 0.0029 by adjusting the parameters to be: $K=58.4, F=0.00018$ and $k a=1072$. It is noted that $F$ is close to zero and the $K$ and $k a$ values are not far from the values from the earlier regression analysis on the Monod model. This suggested fixing $F$ at zero, (hence ignoring any inhibition effect) and just varying the remaining two parameters. In this way, y was improved still further (to 0.0025 ) when $K=37.3 \mathrm{~g} \mathrm{~m}^{-3}$ and $k a=930 \mathrm{~s}^{-1}$.

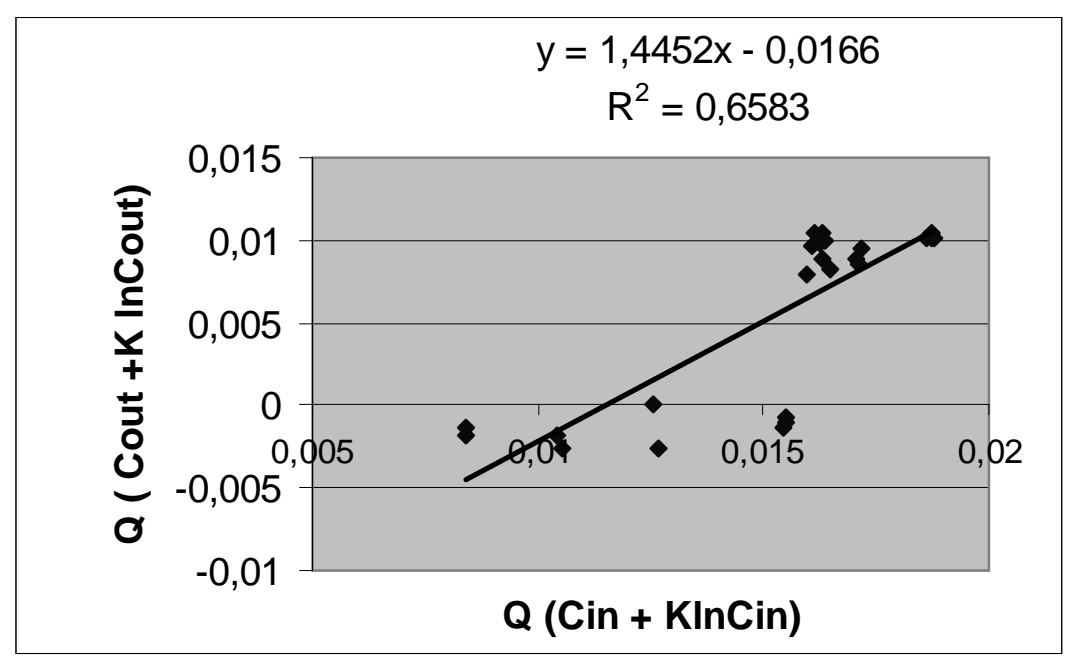

Figure 3 - Monod plotting of the glass beads packing results. 


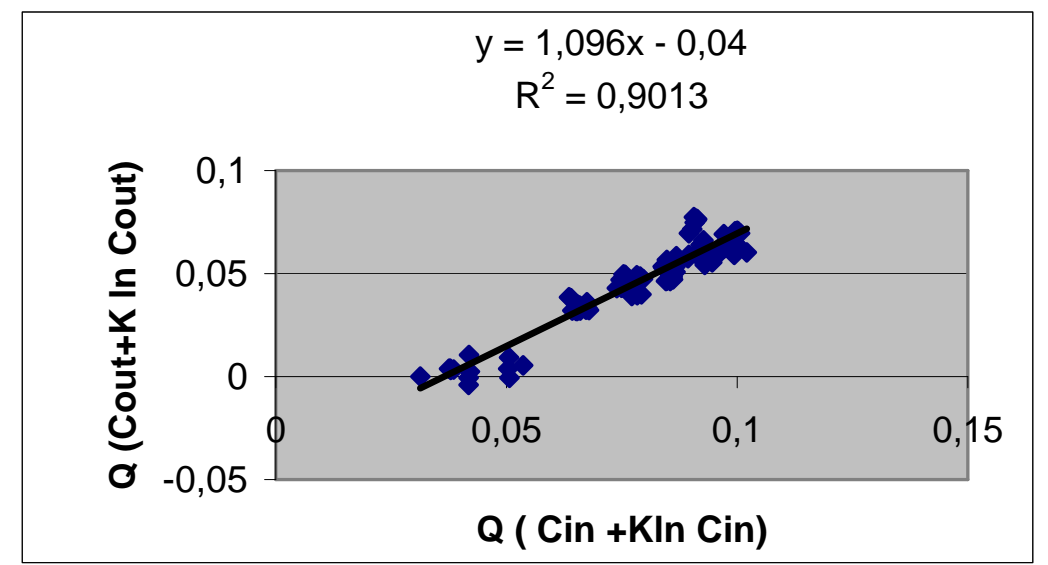

Figure 4 - Cocoa-fibres data and the Monod model.

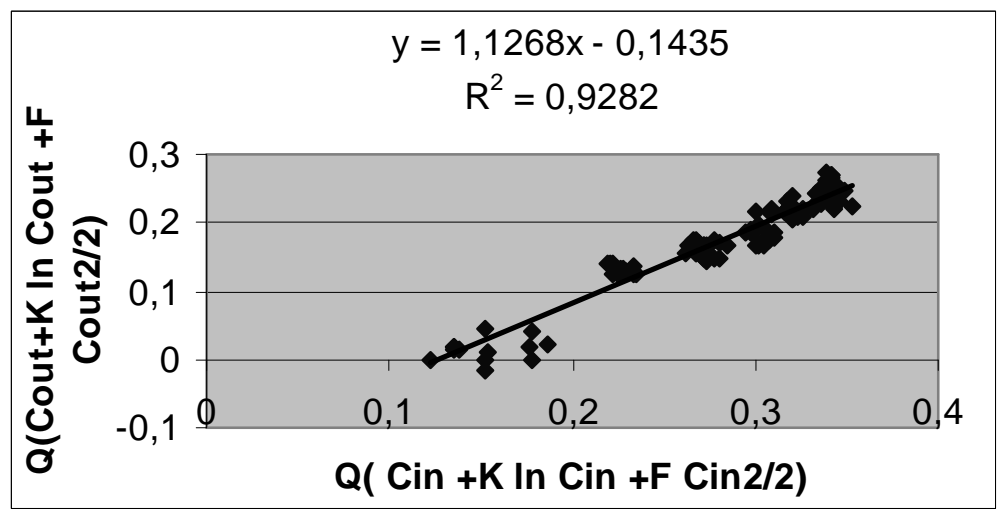

Figure 5 - Cocoa-fibres data and the inhibition model.

\section{DISCUSSION}

In soft polyurethane foam, the cells are immobilized on a very structured particle surface. In addition, due to soft characteristics of these particles, it happened that the bed was compressed and torn off into two parts (a part of it was separated and lifted-up). An increased pressure drop was noted, especially at higher loading rates (high $\mathrm{C}_{\mathrm{in}}$ ) when it was necessary to increase the air flow rate to keep aerobic conditions along the entire bed height (as measured by the dissolved oxygen tension in the outflow). However, the glass beads and well-packed cocoa-fibres did not show out this undesirable behaviour.

The simple modelling of these results showed that the Monod form of kinetic equation was sufficient to represent the observed behaviour of the cells.
Equations 7 and 10 can be used for preliminary design work to size the system for other flow-rates and inlet conditions.

\section{CONCLUSIONS}

1. The results demonstrated the ability of the packed bed reactor to remove the phenol using a variety of packing materials.

2. Most of the collected data can be represented by the Monod form of kinetic equation to predict the apparent rates of microbial degradation of the phenol stream.

3. Typically, the saturation constant, $K$, is about $50 \mathrm{~g} \mathrm{~m}^{-3}, k a$ is around $900 \mathrm{~s}^{-1}$ and the factor, $F$, for inhibition was best set to zero for these experimental results. 


\section{NOMENCLATURE}

$a$ biomass (dry weight) per unit volume of packing, $\mathrm{g}_{\text {cat }} \mathrm{m}^{-3}$

$C$ phenol concentration, $\mathrm{g} \mathrm{m}^{-3}$

DOC dissolved oxygen concentration

$e \quad$ voidage

$F \quad$ inhibition factor, $\mathrm{m}^{3} \mathrm{~g}^{-1}$

HPLC high performance liquid chromatography

$k$ parameter in Monod equation, $\mathrm{m}^{3} \mathrm{~s}^{-1} \mathrm{~g}_{\text {cat }}{ }^{-1}$

$K$ parameter, (saturation constant), in Monod equation, $\mathrm{g} \mathrm{m}^{-3}$

MM mineral medium

$Q \quad$ volumetric flowrate, $\mathrm{m}^{3} \mathrm{~s}^{-1}$

$r \quad$ reaction rate, $\mathrm{g} \mathrm{s}^{-1} \mathrm{~g} \mathrm{cat}^{-1}$

$r^{*} \quad$ zero order rate constant, $\mathrm{g} \mathrm{s}^{-1} \mathrm{~g} \mathrm{cat}^{-1}$

$R^{2} \quad$ coefficient of determination

$V \quad$ volume, $\mathrm{m}^{3}$

$y \quad$ sum of the squares

Subscripts

in inlet condition

out outlet condition

\section{ACKNOWLEDGMENTS}

The project was financially supported by the Czech Scientific Foundation, Project (104/04/0686) and Ministry of Education of the Czech Republic (MSM6046137305).

\section{RESUMO}

Este artigo propõe o uso de uma etapa preliminar de remoção de fenol para redução de picos de carga na entrada de sistemas convencionais de tratamento de efluentes. Um reator de leito fixo (RLF) foi usado, tendo como suportes inertes espuma de poliuretano, vidro poroso e também fibras de coco. Nos experimentos foram controladas a vazão e as concentrações de fenol de entrada e saída. Um simples modelo plug-flow é proposto para representar os resultados. Cinéticas de zero e primeira ordens, Monod e de inibição foram avaliadas. Foi verificado que o modelo de Monod foi o que melhor se ajustou aos dados experimentais, permitindo que gráficos lineares fossem traçados. A constante saturação de Monod, $\mathrm{K}$, é de aproximadamente $50 \mathrm{~g} \mathrm{~m}^{-3}$ e $\mathrm{ka}$ em torno de $900 \mathrm{~s}^{-1}$.

\section{REFERENCES}

Ahuatzi-Chacon, D.; Ordorica-Morales, G.; RuizOrdaz, N.; Cristiani-Urbina, E.; Juarez-Ramirez, C. and Galindez-Mayer, J. (2004), Kinetic study of phenol hydroxylase and catechol 1,2-dioxygenase biosynthesis by Candida tropicalis cells grown on different phenolic substrates. World J. Microbiol. Biotechnol., 20, 695-702.

Bayly, R. C. and Wigmore, G. J. (1973), Metabolism of phenol and cresols by mutants of Pseudomonas putida. J. Bacteriol., 113, 1112-1120.

Bechard, G.; Bisaillon, J. G. and Beaudet, R. (1990), Degradation of phenol by a bacterial consortium under methanogenic conditions. Can. J. Microbiol., 36, 573-578.

Chitra, S.; Sekaran, G.; Padmavathi, S. and Chandrakasan, G. (1995), Removal of phenolic compounds from wastewater using mutant strain of Pseudomonas pictorum. J. Gen. Appl. Microbiol., 41, 229-237.

Ehrhardt, H. M. and Rehm, H. J. (1985), Phenol degradation by microorganisms adsorbed on activated carbon. Appl. Microbiol. Biotechnol., 21, 32-36.

Heipieper, H. J.; Keweloh, H. and Rehm, H. J. (1991), Influence of phenols on growth and membrane permeability of free and immobilized Escherichia coli. Appl. Environ. Microbiol., 57, 1213-1217.

Hinteregger, C.; Leitner, R.; Loidl, M.; Ferchi, A. and Streichsbier, F. (1992), Degradation of phenol and phenolic compounds by Pseudomonas putida EKII. Appl. Microbiol. Biotechnol., 37, 252-259.

Holladay, D. W.; Hancher, C. W.; Scott, C. D. and Chilcote, D. D. (1978), Biodegradation of phenolic waste liquors in stirred-tank, packed-bed and fluidized-bed bioreactors. J. Water Pollution Control Federation, 50, 2573-2589.

Hopp, J. and Huegele, T. (1996), Porositätsbestimmung von biofiltermaterialien. Entsorgungs Praxis., 9, 40-42.

Komárková, E. and Páca, J. (2000), Kinetics of phenol oxidation by Candida tropicalis yeast (in Czech). Chem. Listy, 94, 729.

Komárková, E.; Páca, J.; Klapková, E.; Stiborová, M.; Soccol, C. R. and Sobotka, M. (2003), Physiological changes of Candida tropicalis population degrading phenol in fed batch reactor. Braz. Arch. Biol. Technol., 46, 537-542.

Krug, M. and Straube, G. (1986), Degradation of phenolic compounds by yeast Candida tropicalis HP15. II. Some properties of the first two enzymes of the degradation pathway. J. Basic Microbiol., 5, 271-281.

Krug, M.; Ziegler, H. and Straube, G. (1985), Degradation of phenolic compounds by yeast Candida tropicalis HP15. I. Physiology of growth and substrate utilization. J. Basic Microbiol., 2, 102-110. 
Mörsen, A. and Rehm, H. J. (1987), Degradation of phenol by mixed culture of Pseudomonas putida and Cryptococcus elinovii adsorbed on activated carbon. Appl. Microbiol. Biotechnol., 26, 283-288.

Mörsen, A. and Rehm, H.J. (1990), Degradation of phenol by a defined mixed culture immobilized by adsorption on activated carbon and sintered glass. Appl. Microbiol. Biotechnol., 33, 206-212.

Neujahr, H. Y.; Lindsjo, S. and Varga, J. M. (1974), Oxidation of phenols by cells and cell-free enzymes from Candida tropicalis. Antonie van Leeuwenhoek, 40, 209-216.

Neujahr, H. Y. and Varga, J. M. (1970), Degradation of phenols by intact cells and cell-free preparations of Trichosporum cutaneum. Eur. J. Biochem., 13, 37-44.

Oh, J. S. and Han, Y. H. (1997), Isolation and characterization of phenol degrading Rhodococcus $s p$. DGUM 2011. J. Appl. Microbiol. Biotechnol., 25, 459-463.

Páca Jr., J.; Páca, J.; Kostečková, A.; Stiborová, M.; Sobotka, M. and Gerrard, A. M. (2005), Continuous Aerobic Phenol Degradation by Defined Mix Immobilized Culture in Packed Bed Reactors. Folia Microbiol., 50, 301-308.

Páca, J.; Komárková, E.; Prell, A.; Stiborová, M. and Sobotka, M. (2002), Kinetics of phenol oxidation by Candida tropicalis: effects of oxygen supply rate and nutrients on phenol inhibition. Folia Microbiol., 47, 685-692.
Singer, P. C.; Pfaender, F. K.; Chincilli, J. and Lamb, J. C. (1977), Composition and biodegradability of organics in coal conversion wastewaters. Symp. Proc. Environmen. Aspects. Fuel. Convers. Technol., 3, 461-468.

Stephenson, T. (1990), Substrate inhibition of phenol oxidation by a strain of Candida tropicalis. Biotechn. Lett., 12, 843-846.

Watanabe, K.; Hino, S. and Takahashi, N. (1996), Responses of activated sludge to an increase in phenol loading. J. Ferment. Bioeng., 82, 522-524.

Yang, R. and Humphrey, A. E. (1975), Dynamic and steady state studies of phenol biodegradation in pure and mixed cultures. Biotechnol. Bioeng., 17, 1211-35.

Zache, G. and Rehm, H. J. (1989), Degradation of phenol by a coimmobilized entrapped mixed culture. Appl. Microbiol. Biotechnol., 30, 426-432.

Received: June 29, 2005; Revised: November 11, 2005; Accepted: March 23, 2006. 